\title{
A rare cause of implantable cardiac defibrillator malfunction
}

\author{
Benjamin M Bussmann, ${ }^{\oplus}$ Andrew Cox, Francis Murgatroyd
}

Department of Cardiology, King's College Hospital NHS Trust, London, UK

Correspondence to Dr Benjamin M Bussmann, bussmann.benjamin@gmail.com

Accepted 25 July 2019
Check for updates

(C) BMJ Publishing Group Limited 2019. No commercial re-use. See rights and permissions. Published by BMJ.

To cite: Bussmann BM,
Cox A, Murgatroyd F. BMJ
Case Rep 2019;12:e230435.
doi:10.1136/bcr-2019-
230435

\section{DESCRIPTION}

A previously healthy, 46-year-old man presented with an episode of syncopal ventricular tachycardia secondary to arrhythmogenic right ventricular dysplasia. A dual-chamber implantable cardiac defibrillator (ICD) was implanted without complication. Post-implantation ICD pulse generator box and lead position were confirmed with a plain chest radiograph (figure 1). Six months later, an increase in the device's lead impedance was detected on routine pacemaker check. A repeat chest radiograph was taken and identified rotation of the ICD pulse generator box within its skin pocket, with coiling of the device leads and associated lead retraction in the heart (figure 2). This characteristic rotation of the device and coiling of its leads is known as Twiddler's Syndrome and results in permanent pacemaker malfunction. ${ }^{1}$

Twiddler's syndrome, first described in $1968,{ }^{2}$ is a very rare complication of a permanent pacemaker or ICD implantation occurring with an estimated frequency of $0.07 \% .^{3}$ It usually occurs within the first year following device implantation and is due to patient manipulation of the pacemaker pulse generator box within its skin pocket. Female, obese and elderly patients are at increased risk due to lose subcutaneous tissue. Complications include a failure to pace the heart, diaphragmatic twitching due to ipsilateral phrenic nerve pacing and arm twitching

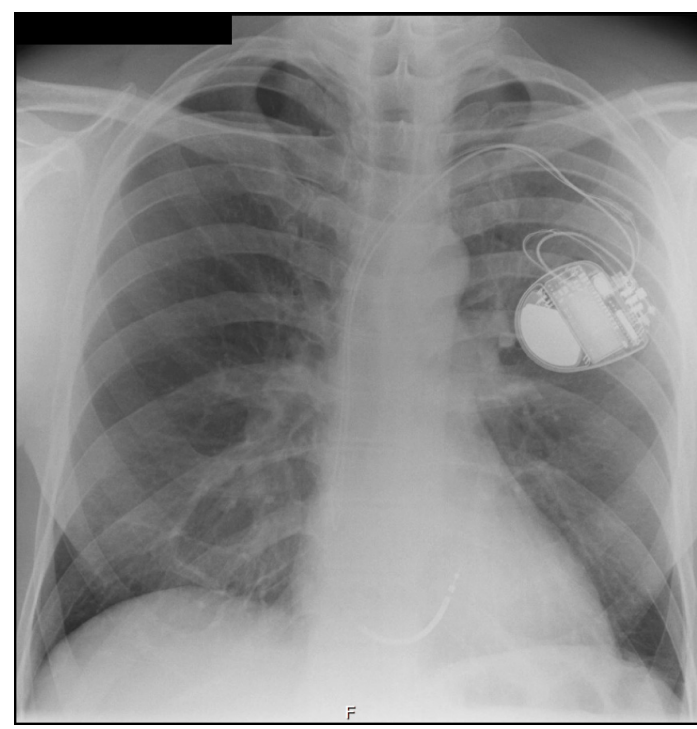

Figure 1 Posterior-anterior erect plain chest radiograph showing a dual-chamber ICD 1 day postimplantation, with appropriate lead positioning.

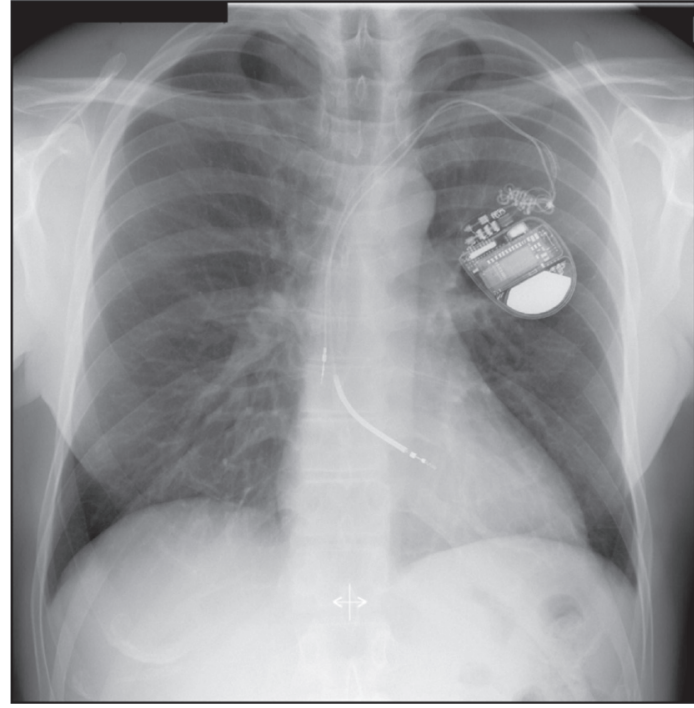

Figure 2 Posterior-anterior erect plain chest radiograph showing a dual-chamber ICD 6 months postimplantation. There is ICD pulse generator box rotation within its subcutaneous pocket with associated coiling of device leads and lead retraction in the heart.

due to brachial plexus stimulation. ${ }^{1}$ In the case of ICDs, inappropriate antitachycardia therapies, including shocks, can result. ${ }^{4}$ Treatment requires surgical repositioning and suture fixation of the pulse generator box and replacement of dislodged leads. At ICD revision in this case, the leads were clearly damaged; they were removed and replaced, and the ICD pulse generator was placed in a subpectoral pocket to prevent further device displacement.

\section{Learning points}

Twiddler's syndrome should be considered in the differential diagnosis for pacemaker malfunction.

- A chest X-ray should be performed to demonstrate characteristic lead displacement in the heart.

- Treatment requires surgical repositioning of the pulse generator box and replacement of damaged leads.

Contributors $B M B$ and $A C$ : drafted the manuscript. $B M B, A C$ and FM: involved in the editing and proof reading of the manuscript for final submission. All authors certify that they have participated sufficiently in the work to take public responsibility for the content in line with criteria set out. 
Images in...

Funding The authors have not declared a specific grant for this research from any funding agency in the public, commercial or not-for-profit sectors.

Competing interests None declared.

Patient consent for publication Obtained.

Provenance and peer review Not commissioned; externally peer reviewed.

\section{REFERENCES}

1 Nicholson WJ, Tuohy KA, Tilkemeier P. Twiddler's syndrome. N Engl J Med 2003:348:1726-7.

2 Bayliss CE, Beanlands DS, Baird RJ. The pacemaker-twiddler's syndrome: a new complication of implantable transvenous pacemakers. Can Med Assoc $J$ 1968;99:371-3.

3 Fahraeus T, Höijer CJ. Early pacemaker twiddler syndrome. Europace 2003;5:279-81.

4 Spencker S, Poppelbaum A, Müller D. An unusual cause of oversensing leading to inappropriate ICD discharges. Int J Cardiol 2008;129:e24-6.

Copyright 2019 BMJ Publishing Group. All rights reserved. For permission to reuse any of this content visit

https://www.bmj.com/company/products-services/rights-and-licensing/permissions/

BMJ Case Report Fellows may re-use this article for personal use and teaching without any further permission.

Become a Fellow of BMJ Case Reports today and you can:

- Submit as many cases as you like

Enjoy fast sympathetic peer review and rapid publication of accepted articles

- Access all the published articles

Re-use any of the published material for personal use and teaching without further permission

Customer Service

If you have any further queries about your subscription, please contact our customer services team on +44 (0) 2071111105 or via email at support@bmj.com.

Visit casereports.bmj.com for more articles like this and to become a Fellow 